\title{
Economic Diversification and Job Creation in the Arab Gulf Countries: Applying a Value Chain Perspective
}

\author{
Martin Hvidt
}

\section{INTRODUCTION}

This chapter aims to discuss economic diversification in the Arab Gulf countries with special emphasis on job creation. The article will use the concept of value chains to provide insight into the type of jobs and especially the knowledge content of these jobs that is likely to be most beneficial to pursue in order for the Gulf countries to further develop their societies. As such, value chains are used solely to illustrate the job categories in the production process. As such, it is not the intention to discuss the Arab Gulf economies within the framework of Global Value Chains (GVCs) by, for example, discussing the path of upgrading their GVC participation or how the Gulf states could reap further benefits from the global value chains.

M. Hvidt $(\bowtie)$

Odense M, Denmark

e-mail: hvidt@sdu.dk

(C) The Author(s) 2021

281

G. Luciani, T. Moerenhout (eds.), When Can Oil Economies Be

Deemed Sustainable?, The Political Economy of the Middle East, https://doi.org/10.1007/978-981-15-5728-6_11 
The issue of diversification has once again reached the top of the political agenda in the region. The '2014 oil price collapse,' which halved the income from oil in year 2015 to 2016 compared to the previous years, demonstrated how volatile the income from oil is and, not least, just how closely tied the performance of the Gulf economics are to the oil income. The crisis, thus, has served as a stark reminder how profoundly dependent the Gulf countries continue to be on oil and gas incomes, and thus how little diversified their economics are.

In addition to discussing the diversification of their economies away from a near total dependency on the revenues from oil and gas, this chapter discusses a second key challenge to the Gulf economies, namely creation of jobs to accommodate their fast-growing population. Contrary to earlier, job creation for the national population has recently become a political aim of the diversification effort.

Normally diversification is viewed within a framework of risk reduction. In economic terms, risk is reduced when an economy changes from relying on one or a few sources of income to a broader variety of sources. Diversifying the Gulf economies thus, usually translates into policies directed at reorienting production from oil and oil-based activities into non-oil activities. This emphasis is in line with the way economists measure diversification, namely as the size of the output from-or the contribution of - the non-oil sector (Jörg 2012, 41).

This chapter, however, argues that, in order to address the issues of employment for a fast-growing number of young entrants to the working age, diversification within the GCC states should rather focus on the content, that is, knowledge and technological content of the jobs created, than on whether or not the jobs are located in the oil sector. In this respect, it does not matter whether or not the jobs are created within or outside the oil sector.

When it comes to job creation, the Gulf countries are facing two significant challenges: first, the demographic challenge visible in the significant growth of the national labor forces. Approximately 500,000 nationals will enter working age ( 25 years) each year during the next decade and a half in the Gulf countries, and even though not each and every one of these individuals will seek employment (salaried work), this still represents a 
formidable challenge. ${ }^{1}$ Saudi Arabia, with a national population of approximately 20 million, is expected to have 400,000 new entrants a year and estimates that 4.5 million new jobs will need to be created before 2030 to meet this challenge (McKinsey Global Institute 2015, 5), while Kuwait, with a native population of a mere 1.3 million, is expected to have 28,000 entrants a year and estimates that 384,000 jobs are required before year 2030 (Tony Blair Associates 2009, 199). Note that these numbers only refer to the national population, thus excluding the migrant workforce.

The second and related challenge is that the public sector, which, until now, has been the main employer of the national labor force, cannot any longer act as the sole provider of jobs for the national population. In other words, the many new entrants among the working age youth must find jobs in the private sector. Thus, the challenge is of a double nature. First, it is to invigorate the private sector so its demands for labor increases and, secondly, to ensure that the national labor forces are willing and able to take the jobs offered in the private sector.

\section{Diversification in the Gulf Countries}

Diversification entails a broad societal process, which transforms a country from a single source of income, in this case oil or gas, to a society where multiple sources of income are generated across the primary, secondary, and tertiary sectors, and where large sections of the population participate. Private sector involvement is generally seen as a necessity for attaining diversification. United Nations Economic and Social Commission for Western Asia (ESCWA) defines diversification as:

Within the context of the GCC countries, economic diversification means reducing overly dependence of the oil sector by developing a non-oil economy, non-oil exports and non-oil revenue sources. By implication, it also means reducing the leading role of the public sector in the GCC economies by promoting the growth of the private sector. (ESCWA 2001, vii)

And the benefits of diversification are, as stated by the General Secretariat for Development Planning in Qatar,

\footnotetext{
${ }^{1}$ Annual number of GCC nationals reaching working age (25 years) over the coming 15 years: Bahrain 13,642; Kuwait 28,434; Oman 54,360; Qatar 7236; Saudi Arabia 402,186; UAE n.a. Calculated by the author on behalf of GLMM data in Hvidt (2018a, 17).
} 
A more diversified economy is inherently more stable, more capable of creating jobs and opportunities for the next generation and less vulnerable to the boom and bust cycles of oil and natural gas prices. (GSDP 2011, 10)

Diversification is not a new strategy among the GCC states. It has been on the political agenda since oil and gas became the main and almost sole source of income in these countries some half a century ago (Henry and Springborg 2001, 26ff; Hvidt 2007; Luciani 2012b; McBrierty and Al Zubair 2004, 116ff; Niblock and Malik 2007; Rivlin 2009, $218 f f ;$ Seznec and Kirk 2011). Notable projects like aluminium smelting in Bahrain, the industrial cities of Yanbu and Jubail in Saudi Arabia, and the ports in Dubai were established in the 1970s with the specific aim of diversifying the economies by means of investing oil money in productive assets. ${ }^{2}$ In addition, extension of education, health services, infrastructure development, and so on has been seen as key elements of the diversification strategy from the earlier days (ESCWA 2001, 8).

Historically, there have been different reasons for diversification. In the 1970s, the finite nature of the oil resources led to a quest to build viable economies which could secure income in the post-oil era. During the 1980s and 1990s, oil prices showed significant volatility and the focus of diversification shifted to counteract fluctuations in state incomes (ESCWA 2001, 3; Hvidt 2013, 11ff).

As I interpret it, today's quest for diversification includes both elements. The finite nature of oil has resurfaced in the form of climate considerations, which aim to 'green' the energy mix. While there is no immediate threat to oil producers from renewable energy systems (e.g. solar panels combined with electric cars) and $\mathrm{CO}_{2}$ neutral nuclear energy, the global climate considerations have and do inflict uncertainties upon the analysts and decision makers in the Gulf as to the long-term call for oil and gas. $^{3}$

The second element is clearly present in today's diversification efforts. For the Gulf countries, their dependence on oil incomes has in fact increased, not decreased over the past two decades, which is reflected in the rising fiscal break-even price of oil. Fifteen years (1999-2014) of rising

\footnotetext{
${ }^{2}$ The Emirate of Dubai possesses meager oil reserves and, as such, the ports were built in order to secure a stable income in the future.

${ }^{3}$ Luciani $(2012 \mathrm{a}, 184)$. He argues, that even though demand for fuel might decrease, the global refining industry will continue to demand sizable inputs of oil and gas in the future.
} 
oil prices have led to significantly higher levels of government spending in the region, and so did attempts to weather the effects of the Arab spring in 2011, which manifested itself as knee-jerk reactions to increase public spending (foremost on public sector salaries), in order to preempt actual or potential public uprisings. Both factors, in combination with increasing population sizes, have resulted in the simple fact that it has become considerably more expensive to run the government in each of the countries. As such, government spending has increased by an annual average of 11 per cent in real terms in 2003-2014. ${ }^{4}$ According to IMF statistics, the break-even oil prices peaked in 2014, with Bahrain at $\$ 103$ per barrel, Kuwait \$54, Oman \$94, Qatar \$56, UAE \$79, Saudi Arabia \$105, ${ }^{5}$ but have, since then, generally fallen as a consequence of the attempt to weather the 2014 oil price collapse through substantial ad hoc measures to cut public spending, that is, within public services (among them hospitals) and development projects and some more permanent features related to reduction in subsidies, for example, on fuel, water, and electricity. ${ }^{6}$

A third element in the historical reasons for diversification seems recently to be present, namely job creation. This is most visible for three countries: Saudi Arabia, Bahrain, and Oman. See especially the Saudi vision 2030.

On a more aggregated level, multiple problems exist in the Gulf economies, which arise from the developmental issues particular to the oil- and gas-driven economies. The oil-based or distribution state model applied in all Gulf states relies on the sale of hydrocarbons, is state-led and statedriven, emphasizes wealth distribution, makes extensive use of migrant labor, and is characterized by a significant underdevelopment of productive assets. However, with rapidly increasing population sizes, and rising popular demands on the governments, this model can no longer adequately support these societies.

Furthermore, this model suffers from problems such as low growth rates, lack of public and private incentives to accumulate human capital, lack of competitiveness in manufacturing, and so on, the likelihood of shocks and spill-over effects in the economies, and various rentier effects.

\footnotetext{
${ }^{4}$ https://www.e-marmore.com/Blog/Economy/January-2018/Why-are-the-breakevenoil-prices-coming-down-for-G.

${ }^{5}$ IMF (2018, Table 6)

${ }^{6}$ Saudi Arabia and UAE have, furthermore, implemented 5 per cent VAT in 2018, and the other Gulf countries are to follow.
} 
All these factors make it imperative for the countries to pursue economic diversification strategies (El-Kharouf et al. 2010, 135ff). ${ }^{7}$

As such, this model generally fails to support further development of the GCC states in two important respects. First, it has not shielded the economies from fluctuations in incomes, and second, and of most interest to this chapter, it has failed to create sufficient job opportunities to accommodate the many new entrants to the job market (Hvidt 2011, 88ff, $2015,30 \mathrm{ff})$.

The current development plans published in the region all emphasize diversification and underline the significant pressure to reform their economies. The Vision 2030 launched in Saudi Arabia in 2016 is an example of the urgency of this reform process and is a statement of how job creation for nationals have accented on the political agenda (Govt. of Saudi Arabia 2016).

Generally, the countries which have the lowest income per capita are in most need of diversification. Saudi Arabia, Bahrain, and Oman are most challenged, while the so-called super rentiers Kuwait, UAE, and foremost, Qatar, experience less urgency to diversify.

\section{Value Chains}

Value chains have generally been studied with the purpose of identifying increased profitability in a given company, either by making each part of the chain more efficient or by adding or deleting parts of the chain. Adding more parts of the value chains hold the potential of reaping more of the value added. In the oil value chain, for example, moving from only undertaking oil production to also, for example, include refining diversifies the product (from crude oil, to a variety of usable products, e.g. gasoline, naphtha, jet fuel, kerosene, etc.). In this perspective, adding steps of the value chain will imply a diversification of the product, and thus of the markets.

And of primary importance for the argument in this chapter, this process of product diversification furthermore holds significant implications for a diversification of job content, and thus skill levels of the workers undertaking the jobs: The more diversification takes place within the value

\footnotetext{
${ }^{7}$ The authors (pp. 135-136) provide a detailed literature review of various economic reasons that make a

diversification strategy imperative for the resource-based GCC states.
} 
chain (adding more stages in the production chain), the greater varieties of jobs will be demanded. Generally, the more primary productive activities are pursued, the higher the demand for supporting activities, which implies jobs related to services. And service-related jobs generally have a higher knowledge content and provide more value added than jobs in 'pure' manufacturing or oil extraction.

The concept of value chains was first introduced by Michael E. Porter in 1985 in his book "Competitive Advantage: Creating and Sustaining Superior Performance." In his book published in 1998, he further develops the concept of a value chain as the tool to analyze the sources of competitive advantages of a firm and define a value chain as the collection of activities that are performed within a firm to design, produce, market, deliver, and support its products (Porter 1998, 36) (Fig. 11.1). ${ }^{8}$

The value chain displays total value and consists of value activities and profit. Value activities are the physically and technologically distinct activities a firm performs (Porter 1998, 38). For companies that produce goods,

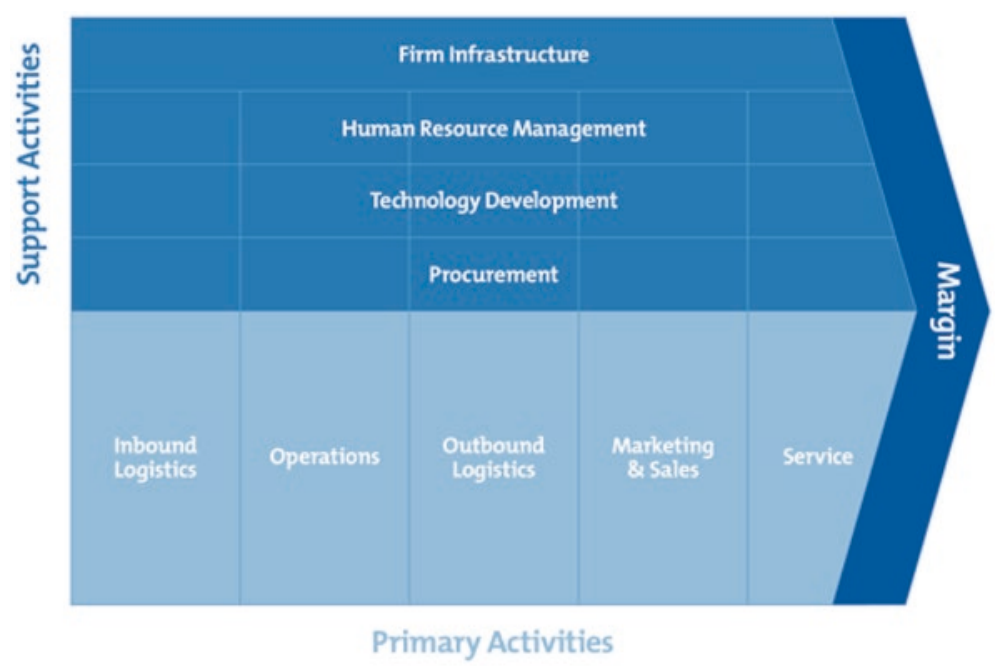

Fig. 11.1 Porter's value chain. (Source: Porter 1998, 7)

\footnotetext{
${ }^{8}$ Porter $(1998,39)$ writes that the "value chain is a theory of the firm that views the firm as being a collection of discrete but related production functions, if production functions are defined as activities.”
} 
the value chain starts with the raw materials used to make their products and consists of everything added before the product is sold to consumers.

As seen in the illustration above, Porter divides a business's activities into two main categories: primary and secondary activities, where the secondary activities are seen to support or to service the primary activities.

Building on this insight, but with a less rigorous division between primary and secondary activities, the so-called 'Smiley-model' was proposed by Stan Shih, founder of Acer computer company in 1992 (Ye et al. 2015, 2) (Fig. 11.2).

The 'Smiley-model' depicts information of the magnitude of valueadded as it relates to various stages in the value chain. The insight derived from this model is that the activities related to manufacturing and assembly, that is to production in itself, yields the least value added (most likely due to the standardization of those processes, and thus exposure to high levels of competition), while the secondary activities related to the product, namely to design, R\&D, innovation, logistics, marketing, and so on, yields high levels of value added. A classic illustration of this relationship is that the manufacturing costs of a jacket, that is, the cost of all inputs and the cost of processing (e.g. cost of labor and use of production facilities) only make up 9 per cent of the price of the final product. Thus, the

\section{"Smiley Face" conceptual modet of the shit to a high vase added. globaly integrated, services economy}

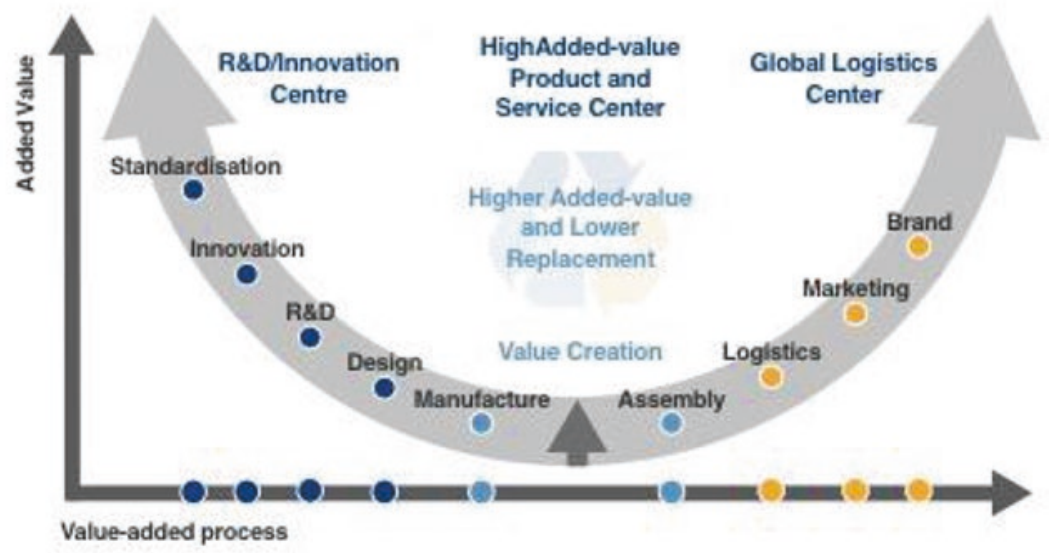

Fig. 11.2 The smiley model. (Source: WTO Director of Trade Abdelhamid Mamdouh Presentation, Doha 27 November 2016) 


\section{The smiley curve, electronics}

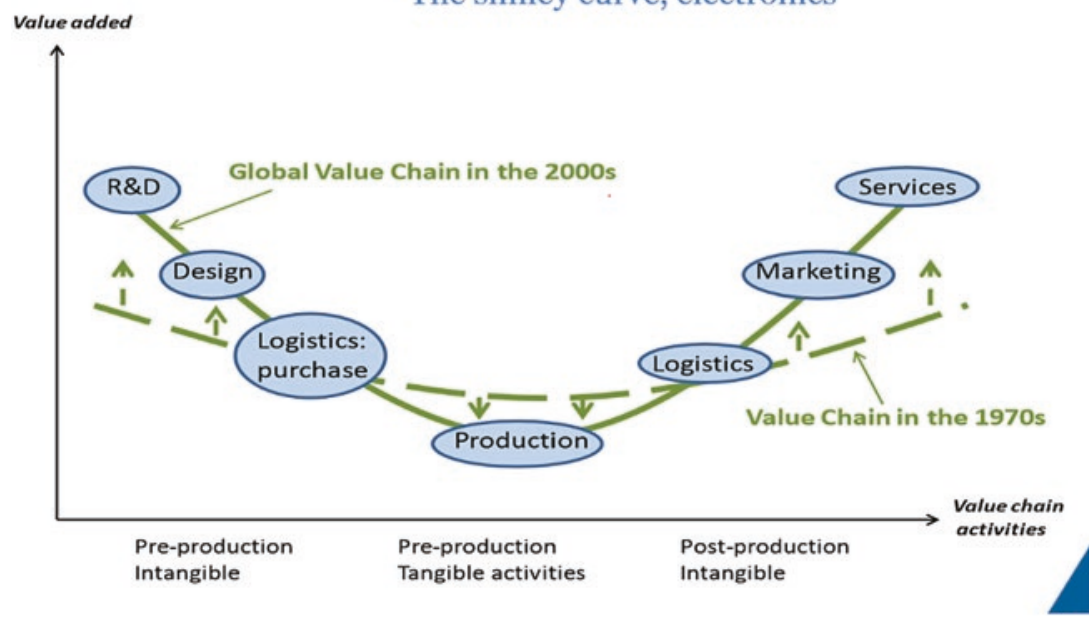

Fig. 11.3 Transition to the smiley curve. (Source: (De Backer 2013, Slide 16))

secondary services and profit make up the remaining 91 per cent (WTO Director of Trade, Presentation, Doha 27 November 2016).

Furthermore, as shown in Fig. 11.3, the Smiley in this particular value chain has attained a more pronounced U-shape over the last four decades. In other words, the value-added in the manufacturing activities compared to the innovation and marketing activities of the chain is getting wider. This development is believed to take place in most value chains under the impression of improved manufacturing processes and increased global competition, thus providing even further incentives for the Gulf states to empathize job creation in the services part of the value chains.

Dubai has spearheaded development toward these goals, for example, through its aviation industry, airports, ports, the financial institutions, for example, Dubai International Financial Center, and so on.

\section{The Challenge of Job Creation in the Gulf}

Diversification is an activity that is pursued both within the oil and gas sectors and outside it, that is, within the oil value chain (upstream, midstream, or downstream) or by economic activities outside the oil value chain, which could be either import substitution activities, which are 
activities that aim to produce the goods or services, which the country otherwise would have to import (building materials, aluminium frames, cladding, cement, steel rebars) (El Beblawi 2011, 185ff), or it could be international services, or advance business services (i.e. logistics, banking, finance, aviation, etc.). For these three categories of economic activities, the aim related to diversification is to attain more jobs within the job categories that provides high value added to the various economic sectors.

\subsection{Diversification Within the Oil and Gas Sector}

As mentioned in the Gulf countries, the oil and gas industry continues to be the dominating source of export earnings and income for the public sector (Hvidt 2013, 13).

The general structure of the Gulf oil sector is that the Gulf countries export the bulk of the oil production basically untreated, namely as crude oil. ${ }^{9}$ This implies an industry where relatively few highly skilled engineers and technicians plus larger contingents of blue-collar workers lift the oil from the ground and transport it to the shipping terminals for export. In a value chain perspective, thus the national oil companies only reap a relatively modest part of the potential profit, but furthermore, lots of potential jobs with high knowledge content (service jobs) associated with the downstream activities (refining, delivery, sales to consumers) are left to other firms and countries. To my knowledge, Kuwait is the only Gulf state which operates the full value chain in the international market. Under the brand of Q8, it operates more than 4400 filling stations in Europe, owns and operates a refinery in Rotterdam, and owns a tanker fleet, and so on. ${ }^{10}$

However, reality is more complex. While it is true that national oil companies in the Gulf countries primarily export their oil as crude, they, however, depart from this picture in two ways. First, the Gulf countries have built structures and capacities to supply their own markets with refined oil products and, as such, operate refineries, filling stations, and handles the

\footnotetext{
${ }^{9}$ In average the Gulf countries exported 78 per cent of their oil production as crude in 2017. This number does not include Bahrain. The number is derived from a comparison between crude oil exports and crude oil production for each country, see OPEC (2018, Table 3.6 and 5.3).

${ }^{10}$ See www.q8oils.com/EN/Mainnavigation/Aboutus/Q8.aspx, accessed 30-05-2018.
} 
logistics related to marketing and transport, but only within each country (Hvidt 2018b).

Second, the Gulf countries, especially Saudi Arabia, Abu Dhabi, and Kuwait have built a substantial refining and petrochemical business aimed first and foremost at the global market (Luciani 2012a). While the share of total crude and gas that is used as feedstock in the petrochemical industry remains relatively low (Luciani 2012a, 184), the Gulf countries have risen to become the world's leading suppliers in petrochemicals (basis products for rubber, plastics, gels, fibers, etc.) (Seznec 2011, 30ff). Since much of the expansion in the Gulf-owned petrochemical industry, both within the Gulf countries and especially on a global scale, are done with foreign partners and through mergers and acquisitions (208ff), it is most likely that the number of nationals employed in this sector, especially in the high-level technological jobs, is relatively small. However, as pointed out by Luciani (2012a, 184), the Gulf countries could and should use their oil and gas resources to develop industrial and progressively technological capabilities for the benefit of the countries, by investments in such high tech industries.

This leads to the conclusion that diversification has in fact been pursued actively within the oil sector in the Gulf countries.

\subsection{Moving Downstream Via Technological 'Upskilling' in the Gulf Countries}

The stated political aim in the Gulf countries is to pursue a diversified knowledge economy according to their development plans. This aim seems to fit well with the fundamentals of the Gulf region. Besides Saudi Arabia, the Gulf countries are made up of small states with tiny native populations. As such, a development strategy which aims to create sizeable numbers of industrial jobs with low or medium knowledge content makes little sense, because the workforce would largely have to be imported. ${ }^{11}$ But to aim for fewer jobs with higher technological or knowledge content,

${ }^{11}$ A similar argument is made in GSDP, Qatar National Development Strategy 2011-2016, March 2011.

(Doha: Qatar General Secretariat for Development Planning, 2011), 55, and by M. A. J. Althani, The Arab.

Spring \& The Gulf States: Time to Embrace Change (London: Profile Books, 2012), 52. 
which yields a better pay targeted at the regions' own population, seems logical.

The labor markets of the GCC countries are of a dual nature wherein nationals, as a part of the social contract, primarily seek employment in the public sector, which is better paid, and offers both a higher level of job security and shorter working hours than jobs in the private sector (McKinsey Global Institute 2015, Exhibit E3). Private sector employment not only entails lower pay, longer working hours, and less job security but is also more competitive, meritocratic, and takes place in a gender-mixed environment, which might present a cultural challenge to segments of the national population (Ulrichsen 2018, 12ff; World Bank 2017, 4).

The key reason for this is that the private sector is overwhelmingly characterized by jobs that are low-skilled and pays low wages, which is facilitated by state policies permitting the sourcing of cheap migrant labor. As such, private sector employment is less attractive to nationals than public sector employment.

In a report titled The Jobs Agenda for the Gulf Cooperation Council Countries, the World Bank (2017, vii) argues that in order to make the jobs more attractive in the longer run salaries must be increased in the private sector and suggests that this should be achieved through reforms that increase the productivity of the private sector by shifting economic activity to "higher value-added sectors, more technology-intensive production, diversified and more sophisticated exports, and technologydriven foreign direct investment (FDI)." As documented by IMF, relative to other countries, productivity gains in the GCC countries have contributed little to growth since 1970. Rather, growth has been attributable to "hiring more hands" and thus neither to capital nor total factor productivity (IMF 2017, 26).

The inclusion of more nationals in the private sector remains however a contentious subject, which relates not only to the salaries paid but also to the motivation, willingness, and ability of the nationals to take a job in this sector (World Bank 2017, vii).

According to ability, that is, the educational qualifications of the nationals, the issue is whether or not the nationals will be able to compete on qualifications with imported skilled workers? ${ }^{12}$ A review of the available indicators of educational achievement in the GCC countries highlights structural problems within and around the educational system that lower

\footnotetext{
${ }^{12}$ Assuming the same salary.
} 
the quality of teaching, minimize research outputs, and lessen the usefulness to society of the education provided. In this respect, it is questionable how well the current educational system prepares its graduates to play an active role in a future knowledge economy (Hvidt 2015, 3lff). At the international level, a link between high incomes from natural resources and lower political emphasis on education is proven (Gylfason 2001).

A second issue is related to the likely success of the political initiatives to make private sector employment attractive to nationals. In all Gulf states, there are policies of localization often termed Emiratization, Omanization, Bahrainzation, or Saudization, which aim to pressure and/ or encourage nationals to take jobs in the private sector on the one hand and, on the other, to open the private sector to employment of nationals, which, as mentioned above, not always is the first choice of employees. One such initiative is the drive to localize production. For example, Saudi Arabia aims to localize 50 per cent of defense spending and 75 per cent of the oil and gas industry, meaning that, all inputs should come from local sources and that a very high percentage of the higher skilled jobs within these sectors should be undertaken by Saudi nationals (Vision 2030). Other measures include implementation of quotas for employing nationals within various categories of private sector firms (e.g. the Saudi Nitaqat system) or even more ridged, restricting certain job functions to nationals only. For example, in January 2018, the Saudi government announced it would add to its growing list of Saudi-only jobs by including the sale of watches, eyewear, medical equipment and devices, electrical and electronic appliances, auto parts, building materials, carpets, cars and motorcycles, home and office furniture, children's clothing and men's accessories, home kitchenware, and confectionery (Young 2018, 17), and Oman which has placed a temporary ban on visas for 87 job categories within information and technology, accounting and finance, marketing and sales, administration and human resources, insurance, information and media profession, and medical professions (Khaleej Times 2018).

Such policies are implemented across the six countries, however, primarily in the three countries with the highest challenge related to unemployment for nationals, namely Saudi Arabia, Oman, and Bahrain.

This chapter focusses solely on the national population. However, it is recognized that presently the migrant labor force outnumber the nationals in the Arab Gulf countries. In Saudi Arabia and Oman, approximately half 
the jobs are held by migrants, while in the smaller Gulf states, such as Qatar and UAE, 80-90 per cent of all jobs are held by migrants. ${ }^{13}$ And these migrants do not only hold jobs as construction workers, drivers, and nannies. An estimated $1 / 3$ of them classify as highly skilled migrants and as such undertake jobs with a high knowledge content both in the private and the public sectors of the Gulf economies (Hvidt 2019, 76). It is generally these jobs which would be of interest to the Gulf economies to replace with their nationals.

Besides the obvious point that it is positive for the national economy if jobs can be undertaken by a national compared to a migrant worker, who usually transfers a substantial part of his/her salary and savings out of the country, the localization efforts of the jobs should be seen as a long-term strategy of 'upskilling' the national labor forces to undertake the kind of jobs to be offered in the high-end of the private sector.

High value-added jobs have, as seen above, a much larger potential for income generation and thus play an active part in attracting the national labor force, but, furthermore, high value-added jobs or high technology jobs come with a much larger development potential, in that jobs with high skill levels or knowledge content not only increases technological change, the key factor behind development, but also increases the ability to quickly adjust to new and changing demands in a rapidly changing world (Hvidt 2019, 76). As pointed out by Ian Bremmer in his latest book Us vs. Them: The Failure of Globalism $(2018,45)$, not only are the profits larger in the technology driven sectors, but, in the next decade, the world will experience an even higher rate of technological change than seen in the previous decades. The technologies of artificial intelligence (AI), robotics, and machine learning have now reached a stage where they profitably can be applied across sectors. These technologies are likely to transform the job market as we know it, placing an even higher premium on the jobs which develop, interact with, and control the digital processes, including the increasingly cheaper and more sophisticated robots. The implication is that the Smiley curve is likely to attain an even more pronounced U-shape, thus leaving countries and sectors which do pursue technological upskilling behind (Bremmer 2018,97). Stated differently by UNIDO and World Economic Forum $(2014,8)$ today, competitiveness of nations or

${ }^{13}$ GLMM Demographic and Economic Data base, table titled: "GCC: Total population and percentage of nationals and non-nationals in GCC countries (national statistics, 2010-2017)," available at http://gulfmigration.org; accessed October 1, 2018. 
city states is less about decreasing costs related to production or transactions, and more about harnessing added value through improving capabilities.

\subsection{Upskilling of the National Labor Force}

Mueller's (2012) analysis of GCC Industrial development is useful to illustrate the process of upskilling the labor force. He points out that non-oil manufacturing industry is likely to make a substantial contribution to further development in the Gulf countries because ( 1 ) it is an essential ingredient of socio-economic development responsible for $1 / 3$ of variation in per capita income across developing countries; (2) a broader manufacturing base is better able to take advantage of new opportunities as compared to an economy which is specialized in a narrow range or resource-based products; and (3) manufacturing industries are drivers of innovation and main source, user, and diffuser of technological progress (Mueller 2012, 140). He notes that the manufacturing sectors in GCC are comparatively weak when it comes to technological status and capabilities, but elaborates on the crucial role that research-intensive industries play for growth in both the manufacturing and the service sectors. In other words, the two sectors are interlinked:

research-intensive industries generate higher growth rates in terms of productivity, value added and high-skilled employment. Besides, researchintensive industries are the source of new cross-cutting technologies, which contribute to enhancing the growth potential of the economy as a whole. The expansion of industrial R\&D activities also stimulates the development of knowledge-intensive services, and it is the interplay of industrial and services sectors that determines the technological capabilities of an economy. (Mueller 2012, 149) (my emphasis)

As such, the process of 'upskilling' the national workforce should be seen as a process, which generally raises the knowledge level in all economic activities throughout a society. This is generally what we understand as a knowledge economy (Hvidt 2015, 27-28).

As mentioned, all Gulf states have statements in their development plans of transforming their economies into such knowledge economies and have taken steps to fulfill those aims (Hvidt 2015, 24ff). However, to 
transform into a knowledge-based economy is neither an easy nor a fast process. It is a comprehensive process, in which appropriate incentives for the population to upgrade their skills and become active participants in this economy have to be established. Among such efforts, the economy must adjust simultaneously both on the supply and on the demand side. As such, private business owners should be able to see their benefit in raising the technological level, while, at the same time, potential employers should approach the labor market with the skills and motivation to adequately fulfill such jobs. And, in all cases, there should be a possibility to make a profit.

A good number of initiatives have been taken over the past two decades to foster this development. For example, the internationalized service sectors, like the aviation industry, the financial sector, shipping services. In addition, the transformation process toward higher-knowledge level jobs is manifest in the stated-owned industries like the aluminum smelters, the oil industry, the shipyards, the property developers, and so on. However, as pointed out above, in discussion of the World Bank report related to the labor market, generally the jobs, especially in the private sector, remain characterized by low efficiency and thus low knowledge content.

\section{Conclusion}

This chapter has discussed diversification and job creation in a value chain perspective. Instead of viewing diversification in a narrow sense, as often done by economists, merely as the percentage of exports deriving from non-oil sectors, the value chain perspective as applied in this article directs the focus for both scholars and decision-makers toward analyzing the type of job and the knowledge content of the jobs, which the policies are attempting to create.

The incorporation of the value chain perspective leads to the understanding that, for diversification to be successful, it is not of particular interest whether or not a newly created economic activity falls within or outside the oil sector, but whether the new activity fosters jobs in the low value-added segment or in the high value-added one. Job creation in the high value-added segments potentially stimulates a virtuous process, which, on the one hand, necessitates upskilling of the labor force but, at the same time, fosters further upskilling. As such, this process includes a 
larger potential for growth and economic development in the long-term perspective. For the virtuous process to gain momentum, the governments in the region need to adjust their policies, for example, related to access to cheap foreign labor, in order to create the right incentives.

\section{REFERENCES}

Backer, Koen De. 2013. Presentation OECD: Interconnected Economies: Benefitting from Global Value Chains - The Czech Republic. OECD,: Presentation Prague, 25 June 2013.

Beblawi, Hazem El. 2011. "Gulf industrialization in perspective." In Industrialization in the Gulf: A Socioeconomic Revolution, edited by JeanFrancois Seznec and Mimi Kirk, 185-197. London: The Center for Contemporary Arab Studies, Georgetown University and Routledge

Bremmer, Ian. 2018. Us vs. Them: The Failure of Globalism. London: Portfolio/Penguin.

El-Kharouf, Farouk, Sulayman Al-Qudsi, and Shifa Obeid. 2010. "The Gulf Corporation Council Sovereign Wealth Funds: Are They Instruments for Economic Diversification or Political Tools?" Asian Economic Papers published by The Earth Institute at Columbia University and the Massachusetts Institute of Technology 9 (1): 124-151.

ESCWA. 2001. Economic Diversification in the Oil-producing Countries: The Case of the Gulf Cooperation Council Economies. New York: United Nations, Economic and Social Commission for Western Asia (ESCWA).

Govt of Saudi Arabia. 2016. Saudi Vision 2030. Riyadh: Government of Saudi Arabia.

GSDP. 2011. Qatar National Development Strategy 2011-2016. Vol. March 2011. Doha: Qatar General Secretariat for Development Planning.

Gylfason, Thorvaldur. 2001. Natural Resources and Economic Growth: From Dependence to Diversification. Paper prepared for an Expert Group Meeting on Economic Diversification in the Arab World organized by The United Nations Economic and Social Commission for Western Asia (UN-ESCWA) in cooperation with the Arab Planning Institute (API) of Kuwait, held in Beirut, Lebanon, 25-27 September, 2001

Henry, Clement M., and Robert Springborg. 2001. Globalization and the Politics of Economic Development in the Middle East. Cambridge: Cambridge University Press.

Hvidt, Martin. 2007. "Public—private ties and their contribution to development: The case of Dubai." Middle Eastern Studies 43 (4): 557-577. https://doi. org/10.1080/00263200701348862. 
2011. "Economic and Institutional Reforms in the Arab Gulf Countries." The Middle East Journal 65 (1): 85-102.

. 2013. Economic Diversification in the GCC Countries-Past Record and Future Trends, Research Paper No. 27: Kuwait Programme on Development, Governance and Globalisation in the Gulf States. London: London School of Economics and Political Science (LSE)

2015. "The State and the Knowledge Economy in the Gulf: Structural and Motivational Challenges." The Muslim World 105 (1): 24-45.

- 2018a. Socio-Econonomic Outlook for the Arab Gulf Countries: Figures of Forecasts. Abu Dhabi: Emirates Policy Center and Arab Strategy Forum.

- 2018b. "The United Arab Emirates: Modernity and Traditionalism in Petroleum Sector Management." In Public Brainpower: Civil Society and Natural Resource Management, edited by Indra Overland, 311-328. Cham: Palgrave Macmillan.

_. 2019. "Exploring the Nexus between Highly-Skilled Migrants, the Kafala System, and Development in the UAE." Journal of Arabian Studies 9 (1): 75-91. https://doi.org/10.1080/21534764.2019.1649827.

IMF. 2017. Regional Economic Outlook: Middle East and Central Asia. October 2017, World Economic and Financial Surveys. Washington D. C.: International Monetary Fund.

- 2018. Regional Economic Outlook: Middle East and Central Asia. Statistical Appendix 0518. Washington D. C.: International Monetary Fund.

Jörg, Beutel. 2012. "Conceptual problems of Measuring Economic Diversificaiton, as Applied to the GCC Economies." In Resources Blessed: Diversification and the Gulf Development Model, edited by Giacomo Luciani. Germany: Gerlach Press.

Khaleej Times. 2018. "Oman temporarily halts expat visas for 87 job roles." In Khaleej Times. Dubai.

Luciani, Giacomo. 2012a. "GCC Refining and Petrochemical Sectors in Global Perspective." In Resources Blessed: Diversification and the Gulf Development Model, edited by Giacomo Luciani, 183-212. Germany: Gerlach Press.

- 2012b. "Introduction: Resources Blessed: Diversification and the Gulf Development Model." In Resources Blessed: Diversification and the Gulf Development Model, edited by Giacomo Luciani. Germany: Gerlach Press.

McBrierty, Vincent, and Mohammad Al Zubair. 2004. Oman: Ancient Civilisation: Modern Nation. Towards a Knowledge and Service Economy. Dublin and Muscat: Trinity College Dublin Press and The Bait Al Zubari Foundation.

McKinsey Global Institute. 2015. Saudi Arabia Beyond Oil: The investment and Productivity Transformation. Riyadh: McKinsey Global Institute / McKinsey\&Company. 
Mueller, Hans-Georg. 2012. "GCC Industrial Development.” In Resources Blessed: Diversification and the Gulf Development Model, edited by Giacomo Luciani, 139-181. Germany: Gerlach Press.

Niblock, Tim, and Monica Malik. 2007. The Political Economy of Saudi Arabia. London: Routledge.

OPEC. 2018. Annual Statistical Bulletin. Geneva: OPEC.

Porter, Michael E. 1998. Competitive Advantage: Creating and sustaining superior performance: With a new introduction. New York: The Free Press.

Rivlin, Paul. 2009. Arab Economies in the Twenty-First Century. Cambridge: Cambridge University Press.

Seznec, Jean-Francois. 2011. "Financing industrialization in the Arab-Persian Gulf." In Industrialization in the Gulf: A Socioeconomic Revolution, edited by Jean-Francois Seznec and Mimi Kirk, 30-43. London: The Center for Contemporary Arab Studies, Georgetown University and Routledge

Seznec, Jean-Francois, and Mimi Kirk (Eds.). 2011. Industrialization in the Gulf: A socioeconomic revolution. London: Routledge in Association with the Center for Contemporary Arab Studies, Georgetown University.

Tony Blair Associates. 2009. Vision Kuwait 2030. Final Report. Kuwait City: Tony Blair Associates.

Ulrichsen, Kristian Coates. 2018. Economic Inclusion in Gulf Cooperation Council (GCC) states: Findings from an expert survey. Washington D.C. : James A. Baker III Institute for Public Policy of Rice University.

UNIDO, and World Economic Forum. 2014. The Future of Manufacturing: Driving Capabilities, Enabling Investments. Geneva, Switzerland: World Economic Forum.

World Bank. 2017. The Jobs Agenda for the Gulf Cooperation Council Countries. Washington D. C.: World Bank Group.

Ye, Ming, Bo Meng, and Shang-jin Wei. 2015. "Measuring Smile Curves in Global Value Chains.” In IDE Discussion Paper No. 530. Japan: Institute of Developing Economies.

Young, Karen E. 2018. The Difficult Promise of Economic Reform in the Gulf. Washington D.C.: James A. Baker III Institute for Public Policy of Rice University. 
Open Access This chapter is licensed under the terms of the Creative Commons Attribution-NonCommercial-NoDerivatives 4.0 International License (http:// creativecommons.org/licenses/by-nc-nd/4.0/), which permits any noncommercial use, sharing, distribution and reproduction in any medium or format, as long as you give appropriate credit to the original author(s) and the source, provide a link to the Creative Commons licence and indicate if you modified the licensed material. You do not have permission under this license to share adapted material derived from this chapter or parts of it.

The images or other third party material in this chapter are included in the chapter's Creative Commons licence, unless indicated otherwise in a credit line to the material. If material is not included in the chapter's Creative Commons licence and your intended use is not permitted by statutory regulation or exceeds the permitted use, you will need to obtain permission directly from the copyright holder. 